\title{
THE ARBOREAL COMPONENT OF A DRY FOREST IN NORTHEASTERN BRAZIL*
}

\author{
RODAL, M. J. N. and NASCIMENTO, L. M. \\ Laboratório de Fitossociologia, Departamento de Biologia, Universidade Federal Rural de Pernambuco, \\ Rua Dom Manoel de Medeiros, s/n, Dois Irmãos, CEP 52171-900, Recife, PE, Brazil \\ Correspondence to: Maria Jesus Nogueira Rodal, Laboratório de Fitossociologia, Departamento de Biologia, \\ Universidade Federal Rural de Pernambuco, Rua Dom Manoel de Medeiros, s/n, Dois Irmãos, \\ CEP 52171-900, Recife, PE, Brazil, e-mail: mrodal@terra.com.br \\ Received March 31, 2004 - Accepted August 31, 2004 - Distributed May 31, 2006
}

(With 4 figures)

\begin{abstract}
The dry forests of northeastern Brazil are found near the coastal zone and on low, isolated mountains inland amid semi-arid vegetation. The floristic composition of these dry montane forests, as well as their relationship to humid forests (Atlantic forest sensu stricto) and to the deciduous thorn woodlands (Caatinga sensu stricto) of the Brazilian northeast are not yet well known. This paper sought to determine if the arboreal plants in a dry forest growing on a low mountain in the semi-arid inland region (Serra Negra, $8^{\circ} 35^{\prime}-8^{\circ} 38^{\prime} \mathrm{S}$ and $38^{\circ} 02^{\prime}-38^{\circ} 04^{\prime} \mathrm{W}$ ) between the municipalities of Floresta and Inajá, state of Pernambuco have the same floristic composition and structure as that seen in other regional forests. In fifty $10 \times 20 \mathrm{~m}$ plots all live and standing dead trees with trunk measuring $\geq 5 \mathrm{~cm}$ diameter at breast height were measured. Floristic similarities between the forest studied and other regional forests were assessed using multivariate analysis. The results demonstrate that the dry forest studied can be classified into two groups that represent two major vegetational transitions: (1) a humid forest/dry forest transition; and (2) a deciduous thorn-woodland/ dry forest transition.
\end{abstract}

Keywords: Brazil, dry forests, tree community, diversity, forest structure.

\section{RESUMO}

\section{O Componente Arbóreo de uma Floresta Seca no Nordeste do Brasil}

As florestas secas do Nordeste do Brasil são encontradas próximo à zona costeira, nos planaltos e em montanhas baixas e isoladas no interior do semi-árido nordestino. A composição dessas florestas secas e sua relação com as florestas úmidas (Floresta Atlântica sensu stricto) e a vegetação arbustivo-arbórea caducifólia espinhosa (Caatinga sensu stricto) do Nordeste do Brasil ainda não estão resolvidas. Este trabalho procura determinar se a flora arbórea da floresta seca que cresce em uma montanha baixa da região semi-árida localizada entre os municípios de Floresta e Inajá, Pernambuco (Serra Negra, $8^{\circ} 35^{\prime}-8^{\circ} 38^{\prime} \mathrm{S}$ e $38^{\circ} 02^{\prime}-38^{\circ} 04^{\prime}$ W) apresenta a mesma composição florística e estrutura observada em outras florestas da região. Foram amostrados todos os indivíduos vivos ou mortos, ainda de pé, com diâmetro do tronco à altura do peito $\geq 5 \mathrm{~cm}$, presentes em 50 parcelas $(10 \times 20 \mathrm{~m})$. A similaridade florística entre Serra Negra e outras florestas da região foram avaliadas usando análises multivariadas. Os resultados demonstram que as florestas secas englobam dois conjuntos florísticos que representam duas transições: (1) transição florestas úmidas/ florestas secas; e (2) transição vegetação arbustivo-arbórea caducifólia espinhosa/floresta seca, onde está localizada Serra Negra.

Palavras-chave: Brasil, florestas secas, comunidade arbórea, diversidade, estrutura.

\footnotetext{
* Research supported by the project: "Floristic composition and diversity of the upland forests of Pernambuco" (Darwin Initiative/ CNPq/APNE/UFRPE).
} 


\section{INTRODUCTION}

Tropical dry forests are found in areas having high year-round temperatures and a well-defined dry season that limits both plant growth and animal activity (Lüettge, 1997). Although climate is seasonally dry, enough moisture is available to support forest vegetation.

The concept of humid and dry tropical forests varies from author to author throughout the phytogeographical regions in which they occur (Richards, 1996). Gentry (1995), for example, using a floristic approach, classified neotropical dry forests as those occurring in areas receiving $700-1600 \mathrm{~mm}$ of rain per year, and having at least five months of less than $100 \mathrm{~mm}$.

Although dry forests cover extensive areas throughout the world, most research efforts have focused on tropical humid forests (Gillespie et al., 2000). Dry forest degradation has been similar to (and often greater than) that seen in humid tropical forests (Gentry, 1995; Mooney et al., 1995; Janzen, 1997). In fact, Trejo \& Dirzo (2000) argue that, for lack of non-disturbed study sites, few quantitative studies have been carried out on dry forests, which have a long history of human use, resulting in either their outright destruction or their conversion into sites with very different vegetation forms.

As the length of the dry season shows extreme variation throughout the tropics, no clear distinction exists between dry and humid tropical forests (Gentry, 1995), with one biome possibly changing into another over a distance of hundreds of miles (Sarmiento, 1972). In addition, although tropical forest researchers have determined that annual precipitation rates and seasonality are closely correlated with plant diversity, this relationship may not always be clear in dry neotropical forests (Gillespie et al., 2000). Furthermore, Gentry (1995) attributed differences between dry forests mainly to biogeographical factors, since these forests show no significant increases in either species richness or diversity as rainfall increases.

Pennington et al. (2000) noted that in seasonally dry regions of Brazil the diverse forest and savanna types have been traditionally defined as belonging to the Amazonian forest, Atlantic forest, or Cerrado biomes. These same authors observed that the term "seasonally dry forest" includes several forest types (such as forests in more humid areas, and shrub vegetation in drier regions), and that the largest areas of seasonally dry forests in South America are found in northeastern Brazil (the Caatinga biome, which extends southward almost to the state of Minas Gerais). For these authors, the dry forests on the low hills in the semi-arid region of northeastern Brazil represent the most favorable end of a humidity gradient that trails off into the deciduous thorn woodland (DTW) (Caatinga sensu stricto).

However, other authors regard these same forests as part of the Atlantic coastal forest biome that extends all along the Brazilian seacoast, between the states of Rio Grande do Norte and Rio Grande do Sul. This biome is composed of a number of different vegetation types, ranging from humid forest (Atlantic forest sensu stricto) to seasonally dry forest (Atlantic forest sensu lato), within an area of high environmental heterogeneity (Coimbra-Filho \& Câmara, 1996). While the bulk of the Atlantic coastal forest (ACF) hugs the coast, it can extend inland along rivers into the savanna region (Cerrado) (Oliveira-Filho \& Ratter, 2000), and can cover the tops of low mountains in the Borborema Highlands or those scattered throughout the semi-arid region of northeastern Brazil (Joly et al., 1999). The ACF has been intensely studied in southeastern Brazil (Scudeller et al., 2001), while its floristic composition and physiognomy are much less studied in the northeastern part of the country, with the possible exception of the forests in southern Bahia (Thomas et al., 1998).

The majority of plant surveys in northeastern Brazil have concentrated on humid forests (Cavalcanti, 1985; Borges, 1992; Guedes, 1998; Tavares et al., 2000; Siqueira et al., 2001; Lins-eSilva \& Rodal, in press), although recent years have seen an increase in surveys of dry forests (Correia, 1996; Moura, 1997; Nascimento, 2001; Ferraz et al., 2003; Andrade \& Rodal, 2004) or in DTW (Araújo et al., 1995; Figueirêdo et al., 2000; AlcoforadoFilho et al., 2003; Ferraz et al., 2003). However, no studies have been published on the isolated dry forests on low mountains of northeastern Brazil's semi-arid areas nor have floristic composition and structure of these forest areas been compared with one another.

In the absence of sufficient data on this area, the present study sought to characterize the arboreal component of a dry forest community in the low 
mountains of Brazilian semi-arid northeastern region (Serra Negra) and to answer the following questions: (1) Are there floristic and structural differences among dry forests in northeastern Brazil? and (2) do the dry and humid forests in northeastern Brazil represent a single vegetation unit?

\section{METHODS}

\section{Study area}

The Serra Negra Biological Reserve $\left(8^{\circ} 35^{\prime}\right.$ $-8^{\circ} 38^{\prime} \mathrm{S}$ and $38^{\circ} 02^{\prime}-38^{\circ} 04^{\prime} \mathrm{W}$ ), between the municipalities of Floresta and Inajá, Pernambuco state, is a low mountain located on a residual plain in the semi-arid region of northeastern Brazil. According to Andrade (1954) and Dantas (1980), the Serra Negra region, which originated in the Cretaceous, has a cuesta landform. The landscape is a relict plain derived from a larger sedimentary formation that was reworked throughout a series of paleo-environments under varying humidity conditions. The reserve itself contains $1,100 \mathrm{ha}$, and is located approximately $400 \mathrm{~km}$ from the Atlantic coast, between the municipalities of Floresta and Inajá, in Pernambuco state (IBAMA, 1989). The forest-covered summit measures $800-900 \mathrm{~m}$ in width, and is approximately $3,000 \mathrm{~m}$ long in an E/NE-W/SW direction. According to Andrade (1954), the maximum altitude is $963 \mathrm{~m}$ asl (Fig. 1).

Although no systematic rainfall records exist for the study area, estimates of precipitation based on regression (Rodal, 1983) show that the average annual rainfall on the summit is approximately $900 \mathrm{~mm}$ per year. Average annual temperature is $25.3{ }^{\circ} \mathrm{C}$, with an absolute maximum of $38^{\circ} \mathrm{C}$, and an absolute minimum of $8^{\circ} \mathrm{C}$ (IBAMA, 1989). Soils are deep and sandy (Jacomine et al., 1973).
The altitude of Serra Negra, combined with its exposure to humid southeast winds from the São Francisco River valley, results in an amenable local climate in the midst of an otherwise semiarid landscape. A dense forest, with trees such as Manilkara salzmanii (ADC.) Lam. (Sapotaceae) and Trichilia emarginata (Turcz.) C. DC (Meliaceae) reaching up to $35 \mathrm{~m}$ in height, covers the Serra Negra peak.

The main forested area in the eastern part of the Brazilian northeast (Alagoas, Pernambuco, and Paraíba states) is located principally between the coastal plain and the Borborema Highlands. The latter consists of a series of highly weathered massifs, composed mainly of metamorphosed rocks, such as gneisses and eruptive granites (Moreira, 1977). These massifs are the most outstanding regional geomorphological feature, the great diversity of which is paralleled by that of its vegetation, which includes deciduous thorn woodland (Alcoforado-Filho et al., 2003), as well as both dry (Nascimento, 2001) and humid forests on the eastern slopes (Tavares et al., 2000). Both of these forest types are known as brejos de altitude.

Down from these highlands and eastward to the sea, Precambrian rocks of the Borborema Highlands give way to the hills and coastal plains of the Barreiras Formation (Tertiary) whose vegetation ranges from humid (Atlantic forest sensu stricto) (Siqueira et al., 2001) to dry forest (Atlantic forest sensu lato) (Andrade \& Rodal, 2004). The western slopes, which are dominated by DTW vegetation (Rodal, 2001) of the Borborema, descend steeply towards the semi-arid inland region known as the Depressão Sertaneja. Scattered throughout this inland depression are a number of low mountains covered by dry forests, such as the Serra Negra.

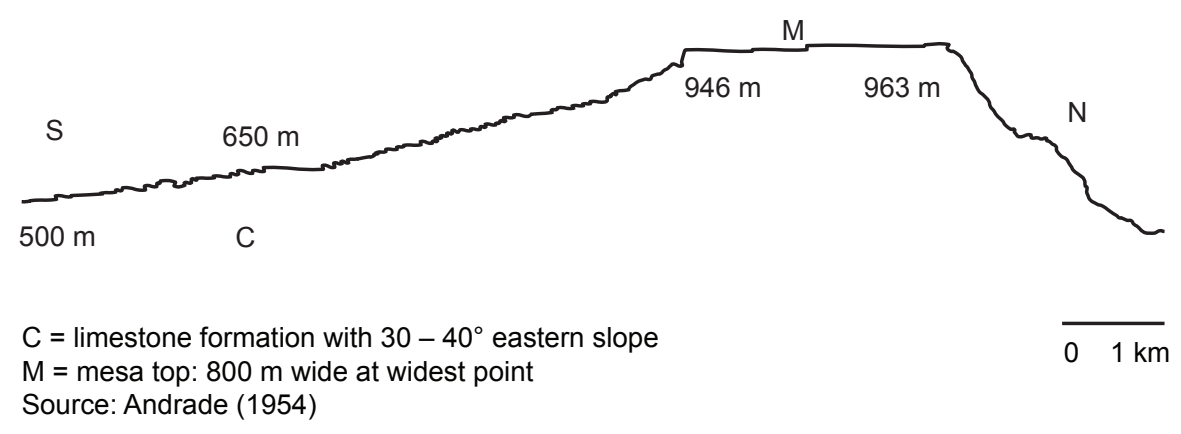

Fig. 1 - Schematic diagram of Serra Negra Mountain, Pernambuco state, Brazil. 
According to Sampaio (1995) and Rodal (2001), the climate in Pernambuco state (where most of the quantitative surveys analyzed in this study were undertaken) is a complex combination of various climatic elements (precipitation, temperature, wind, etc.), which in turn are influenced by physiographic factors such as orography (Borborema Highlands) and continent effect. Precipitation diminishes inland (westward), decreasing from $2000 \mathrm{~mm}_{\text {year }}{ }^{-1}$ in the coastal plains to $500 \mathrm{~mm}_{\text {year-1 }}{ }^{-1}$ in the semi-arid depression. Temperatures are generally much higher in these inland areas, although the Borborema Highlands are a local exception, having slightly lower temperatures than the surrounding areas, especially during the night.

\section{Field methods}

Fieldwork was carried out for 13 consecutive months, between January 1997 and January 1998. Fifty $10 \times 20 \mathrm{~m}$ plots on the top of the mountain (930-940 $\mathrm{m}$ asl) were set along three parallel transects separated from one another by $100 \mathrm{~m}$. The plots themselves were spaced $20 \mathrm{~m}$ apart from one another. All trunks (living and dead), except for lianas and palms, with $\mathrm{a} \geq 5 \mathrm{~cm}$ diameter at breast height $(\mathrm{DBH})$ were marked and identified to species; their diameters were recorded, and heights measured using an Abney Level.

\section{Data analysis}

Voucher specimens were processed, identified, and stored at the Professor Vasconcelos Sobrinho Herbarium (PEUFR) of the Universidade Federal Rural de Pernambuco (UFRPE). The classification system used follows Cronquist (1981).

To identify different height classes, a $4 \mathrm{~m}$ interval was used to evaluate the species, the number of trunks, and their basal areas (1.3-4 m, 4.1-8 m, ..., 32.1 + m). Density, frequency, and basal area (Kent \& Coker, 1992) for all families and species were calculated using FITOPAC 2 software (Shepherd, 1995). The Cover Importance Index (Matteucci \& Colma, 1982) and Shannon Diversity Index (Magurran, 1988) for families and species were also calculated.

In order to identify the similarities between the Serra Negra and the other forests in Pernambuco, multivariate analyses were performed using presence/absence of species in 12 surveys, including the study area. The surveys covered humid forests (Tavares et al., 2000; Siqueira et al., 2001; Lins-eSilva \& Rodal, in press); dry forests (the present survey; Correia, 1996; Moura, 1997; Nascimento, 2001; Andrade \& Rodal, 2004), specifically at $900 \mathrm{~m}$ asl (Ferraz et al., 2003) and $700 \mathrm{~m}$ asl (Rodal et al., accepted); and DTW (Ferraz et al., 2003), specifically at $500 \mathrm{~m}$ asl (Rodal et al., accepted). The Kendall correlation coefficient was used to test the relationship between altitude and basal area in these humid and dry forests (Ayres et al., 2000).

The terminology used to define montane (altitude $>600 \mathrm{~m}$ asl) and lowland forests (altitude $<100 \mathrm{~m}$ ) followed Veloso et al. (1991). The authors that have worked in the northeastern forests differ with respect to nomenclature used in classifying ombrophylous (humid) and seasonal (dry) forests. For example, Andrade \& Rodal (2004) employed definitions suggested by Veloso et al. (1991) while Tavares et al. (2000) used floristic composition to distinguish forest types. The quantitative surveys used in our comparative analyses classified forests as either humid or dry in accordance with the descriptions supplied by the various authors cited above. Table 1 presents the analyzed surveys listed by municipality and includes bibliographic references, geomorphology (Silva et al., 1993), altitude, and precipitation. Total annual rainfall at each survey site was obtained from either the studies themselves or SUDENE (1990).

All species present in more than one survey were taken into consideration, regardless of the number of individuals in each. Scientific names listed were synonymized according to the literature. Cluster analysis and principal component analysis (PCA) were performed using the same matrix. For the cluster analysis, the Sørensen index, and the weighted pair-group method using arithmetic averages (WUPGMA) were employed. For the PCA analysis, a variance-covariance matrix was used. Analyses were undertaken using FITOPAC 2 software (Shepherd, 1995).

\section{RESULTS}

\section{Floristic composition and structure of the Serra Negra Forest}

In 50 sample plots, a total of 1,525 stems (including dead ones) ha ${ }^{-1}$ were found, with a total 


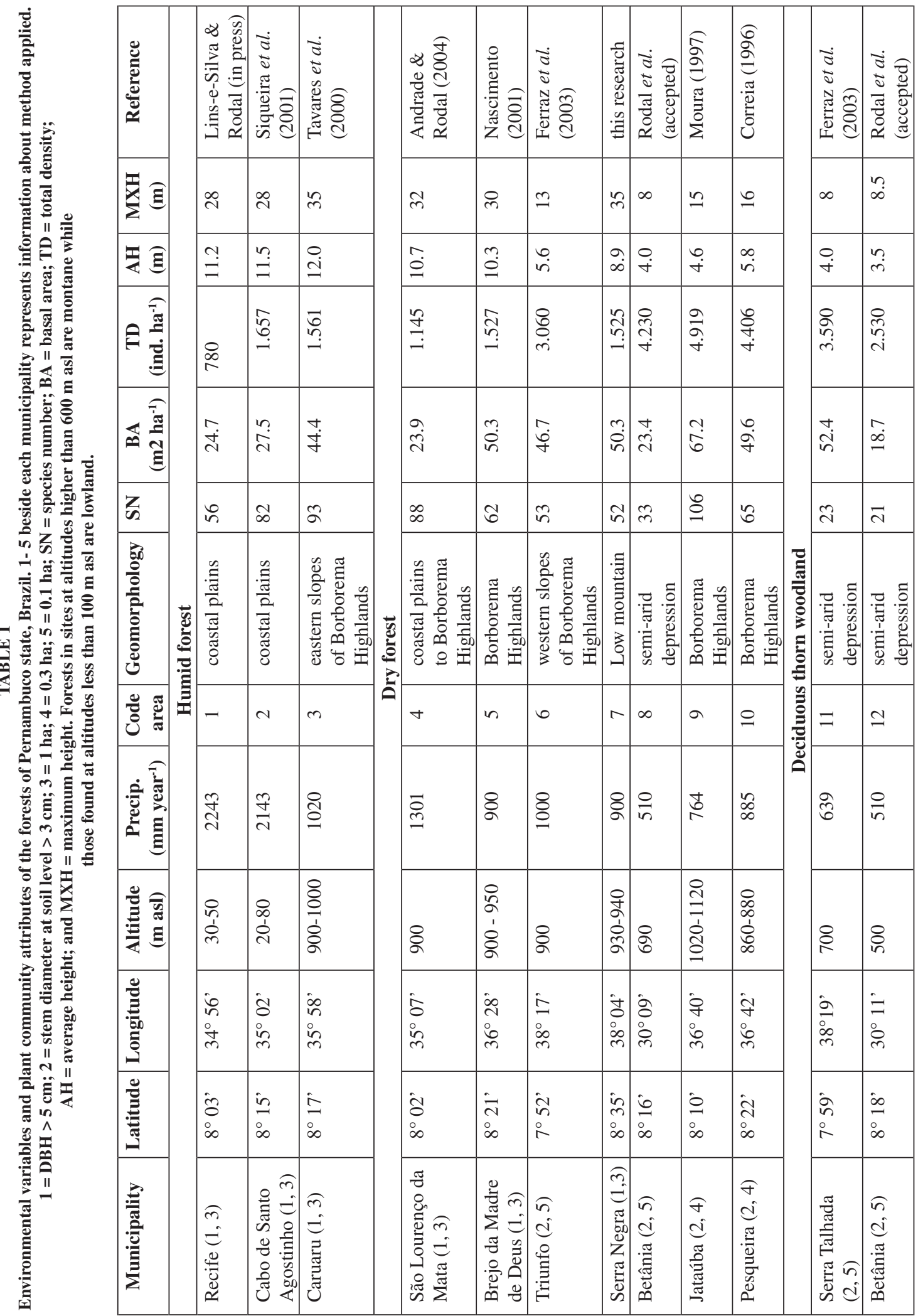


basal area of $50.32 \mathrm{~m}^{2} \mathrm{ha}^{-1}$. Average tree height was $8.9 \mathrm{~m}( \pm 5.55 \mathrm{~m})$, while the average maximum height per plot was $22.8 \mathrm{~m}$. Average diameter was $14 \mathrm{~cm}( \pm 14.74 \mathrm{~cm})$, with an average maximum diameter per plot of $64.2 \mathrm{~cm}$. Fig. 2a shows that the majority of trunks were less than $10 \mathrm{~m}$ tall. Approximately $50 \%$ of the total basal area was accounted for by only $7 \%$ of the total number of stems (103), all of which were over $20 \mathrm{~m}$ tall. While taller trees accounted for most of the basal area (Fig. 2b), the largest number of species was found among trees less than $12 \mathrm{~m}$ tall (Fig. 2c).

Basal-area distribution and trunk number per height class indicate a double-layered stratification, with emergent trees between 28 and $35 \mathrm{~m}$ tall.
The understory occupies the 4 to $12 \mathrm{~m}$ layer, with canopy beginning at $16 \mathrm{~m}$.

Fifty-one species belonging to 30 families were found in the survey (Table 2). Shannon diversity index (H') for families was 2.06 nats ind.$^{-1}$ The most species-rich family was Myrtaceae (10 species), followed by Fabaceae and Sapotaceae (3 each). These three families accounted for $34 \%$ of all species recorded.

The families most heavily represented in the importance cover index (IC) were Myrtaceae, Mimosaceae, Meliaceae, Lauraceae and Urticaceae. All showed a reduced number of species, except Myrtaceae, which accounted for $49.38 \%$ of the total density and $18.19 \%$ of the total basal area.
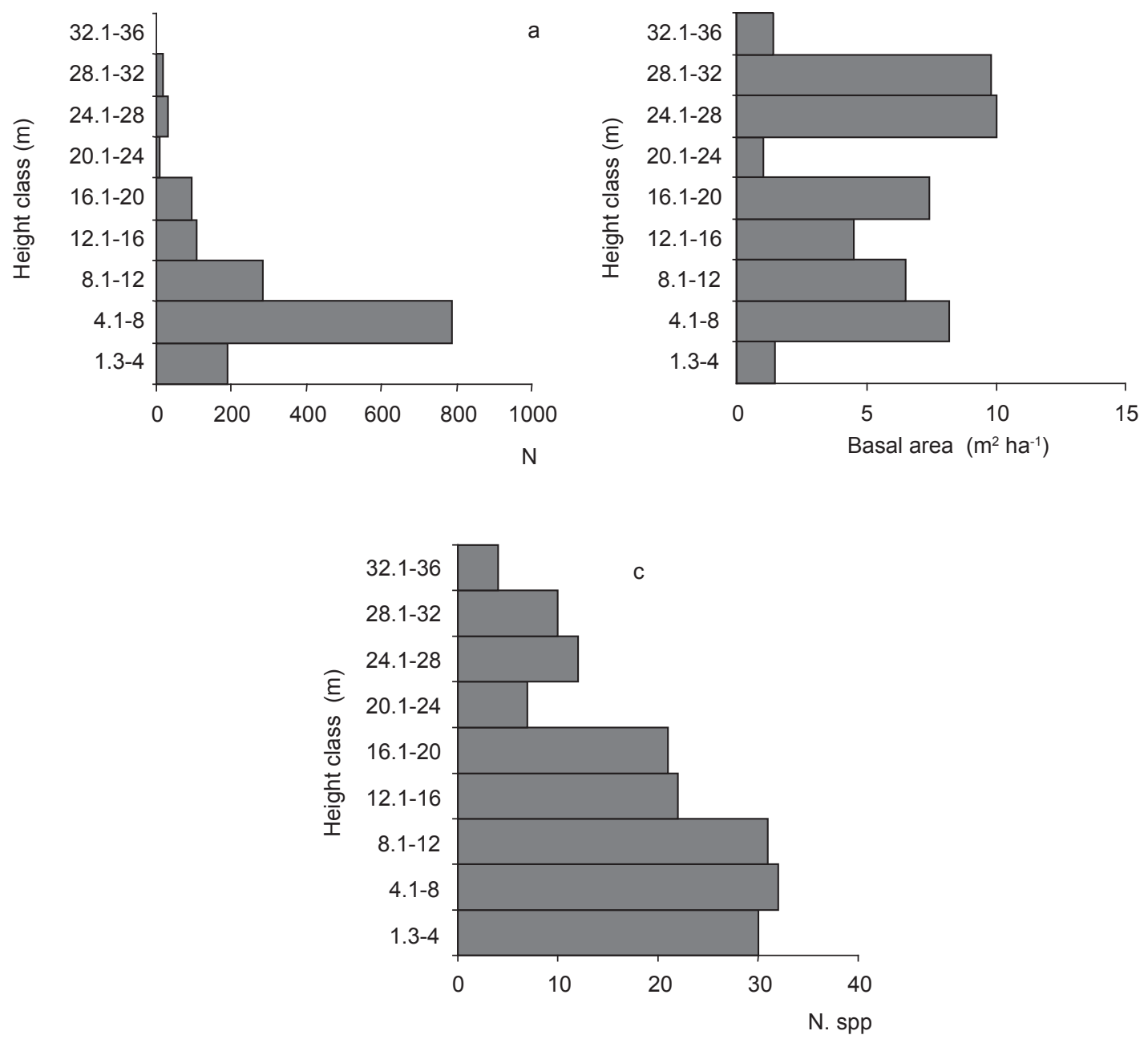

Fig. 2 - Distribution of number of stems (a); basal area (b); and number of species (c) per height class in montane dry forest of the Serra Negra Biological Reserve. $\mathrm{N}=$ number of stems, N. spp. = number of species. 
TABLE 2

Tree species sampled in montane dry forest in the Serra Negra Biological Reserve, Pernambuco state, Brazil. NS = number of trunks; $\mathrm{RD}=$ relative density $(\%) ; \mathrm{RDo}=$ relative dominance $(\%) ; \mathrm{RF}=$ relative frequency $(\%)$; and $\mathrm{IC}=$ importance cover. Names after families indicate names of those who identified the plant species and their herbaria.

\begin{tabular}{|c|c|c|c|c|c|c|}
\hline Families /Species & NS & RD & RDo & $\mathbf{R F}$ & IC & $\% \mathrm{IC}$ \\
\hline Myrtaceae (G.M.Barroso - RB) & 753 & 49.38 & 18.19 & 12.5 & 67.56 & 33.78 \\
\hline 1. Myrcia fallax (Rich.) DC & 547 & 35.87 & 10.14 & 8.96 & 46.00 & 23.00 \\
\hline 2. Myrcia multiflora (Lam.) DC. & 67 & 4.39 & 1.92 & 4.69 & 6.31 & 3.16 \\
\hline 3. Myrciaria floribunda (H.West ex Willd.) O.Berg & 45 & 2.95 & 3.23 & 4.26 & 6.18 & 3.09 \\
\hline 4. Eugenia lambertiana var. hispidula McVaugh & 45 & 2.95 & 1.05 & 1.07 & 4.00 & 2.00 \\
\hline 5. Calyptranthes cf multiflora Poepp. Ex O.Berg & 17 & 1.11 & 0.53 & 1.49 & 1.64 & 0.82 \\
\hline 6. Campomanesia dichotoma (O. Berg) Mattos & 9 & 0.59 & 0.41 & 1.07 & 1.00 & 0.50 \\
\hline 7. Calyptranthes dardanoi Mattos & 6 & 0.39 & 0.60 & 1.07 & 1.00 & 0.50 \\
\hline 8. Myrcia caesia O.Berg & 8 & 0.52 & 0.21 & 1.49 & 0.73 & 0.37 \\
\hline 9. Psidium personii McVaugh & 5 & 0.33 & 0.04 & 0.85 & 0.37 & 0.19 \\
\hline 10. Eugenia hirta O. Berg & 4 & 0.26 & 0.05 & 0.43 & 0.31 & 0.16 \\
\hline Mimosaceae & 155 & 10.16 & 10.11 & 11.46 & 20.27 & 10.14 \\
\hline 11. Inga thibaudiana $\mathrm{DC}$. & 103 & 6.75 & 7.40 & 7.46 & 14.15 & 7.08 \\
\hline 12. Albizia polycephala (Benth.) Killip ex Record & 52 & 3.41 & 2.71 & 3.2 & 6.12 & 3.06 \\
\hline Sapotaceae (T.B.Pennington - K) & 29 & 1.90 & 17.73 & 3.39 & 19.63 & 9.82 \\
\hline 13. Manilkara salzmanii (ADC.) Lam. & 25 & 1.64 & 17.40 & 2.35 & 19.04 & 9.52 \\
\hline 14. Pouteria ramiflora (Mart.) Radlk. & 2 & 0.13 & 0.29 & 0.43 & 0.42 & 0.21 \\
\hline 15. Sideroxylon obtusifolium (Roem.\& Schult) T.D. Penn. & 2 & 0.13 & 0.04 & 0.21 & 0.17 & 0.09 \\
\hline Meliaceae & 82 & 5.38 & 9.88 & 7.03 & 15.26 & 7.63 \\
\hline 16. Trichilia emarginata (Turcz.) C. DC. & 82 & 5.38 & 9.88 & 5.76 & 15.26 & 7.63 \\
\hline Combretaceae (I. B. Loyola - PEUFR) & 40 & 2.62 & 10.28 & 6.25 & 12.90 & 6.45 \\
\hline 17. Terminalia brasiliensis (Cambess ex A. St.-Hil.) Eichler & 39 & 2.56 & 10.24 & 4.9 & 12.80 & 6.40 \\
\hline 18. Buchenavia capitata (Vahl) Eichler & 1 & 0.07 & 0.04 & 0.21 & 0.11 & 0.06 \\
\hline Phytolaccaceae & 7 & 0.46 & 9.32 & 1.56 & 9.78 & 4.89 \\
\hline 19. Gallesia integrifolia (Spreng.) Harms & 7 & 0.46 & 9.32 & 1.28 & 9.78 & 4.89 \\
\hline Lauraceae (R.Roxana - UFP) & 68 & 4.46 & 3.99 & 6.51 & 8.45 & 4.22 \\
\hline 20. Ocotea duckei Vattimo & 68 & 4.46 & 3.99 & 5.33 & 8.45 & 4.23 \\
\hline Nyctaginaceae (A.Furlan - HRCB) & 31 & 2.03 & 3.49 & 4.95 & 5.52 & 2.76 \\
\hline 21. Guapira opposita (Vell.) Reitz & 31 & 2.03 & 3.49 & 4.05 & 5.52 & 2.76 \\
\hline Apocynaceae (M.F.Sales - PEUFR ) & 34 & 2.23 & 2.91 & 4.69 & 5.14 & 2.57 \\
\hline 22. Aspidosperma cf. illustre (Vell.) Kuhlmann \& Piraja & 7 & 0.46 & 2.27 & 1.49 & 2.73 & 1.37 \\
\hline 23. Aspidosperma sp. & 27 & 1.77 & 0.64 & 2.77 & 2.41 & 1.21 \\
\hline Urticaceae & 58 & 3.80 & 0.85 & 4.43 & 4.65 & 2.33 \\
\hline 24. Urera baccifera Gaudich. Ex Wedd. & 58 & 4.00 & 0.85 & 3.62 & 4.65 & 2.33 \\
\hline Euphorbiaceae (M. F. Araújo - PEUFR) & 46 & 3.02 & 0.67 & 4.95 & 3.69 & 1.84 \\
\hline 25. Maprounea guianensis var. guianensis Aubl. & 37 & 2.00 & 0.36 & 2.99 & 2.79 & 1.40 \\
\hline 26. Sebastiania brasiliensis Spreng. & 9 & 0.59 & 0.31 & 1.28 & 0.90 & 0.45 \\
\hline Celastraceae (R. Okano - V) & 33 & 2.16 & 1.23 & 3.13 & 3.39 & 1.69 \\
\hline 27. Maytenus obtusifolia Mart. & 28 & 1.84 & 1.10 & 2.35 & 2.94 & 1.47 \\
\hline 28. Maytenus aff. evonymoides Reissek & 5 & 0.33 & 0.12 & 0.85 & 0.45 & 0.23 \\
\hline Clusiaceae & 11 & 0.72 & 1.39 & 1.30 & 2.11 & 1.06 \\
\hline 29. Garcinia gardneriana (Planch. \& Triana) Zappi & 11 & 0.72 & 1.39 & 1.07 & 2.11 & 1.06 \\
\hline
\end{tabular}


TABLE 2

Continued...

\begin{tabular}{|c|c|c|c|c|c|c|}
\hline Families /Species & NS & RD & RDo & RF & IC & $\% \mathrm{IC}$ \\
\hline Erythroxylaceae & 13 & 0.85 & $\mathbf{0 . 5 8}$ & 3.13 & 1.44 & 0.72 \\
\hline 30. Erythroxylum sp. & 8 & 0.52 & 0.52 & 1.71 & 1.04 & 0.52 \\
\hline 31. Erythroxylum macrochaetum Miq. & 5 & 0.33 & 0.06 & 0.85 & 0.39 & 0.20 \\
\hline Proteaceae & 9 & 0.59 & 0.36 & 1.56 & 0.95 & 0.48 \\
\hline 32. Roupala paulensis Sleumer & 9 & 0.59 & 0.36 & 1.28 & 0.95 & 0.48 \\
\hline Moraceae & 6 & 0.39 & 0.52 & 1.56 & 0.91 & 0.46 \\
\hline 33. Ficus sp. & 6 & 0.39 & 0.52 & 1.28 & 0.91 & 0.46 \\
\hline Rutaceae & 9 & 0.59 & 0.22 & 2.08 & 0.81 & 0.41 \\
\hline 34. Zanthoxylum acutifolium Engler & 7 & 0.46 & 0.21 & 1.49 & 0.67 & 0.33 \\
\hline 35. Zanthoxylum rhoifolium Lam. & 2 & 0.13 & 0.01 & 0.21 & 0.14 & 0.07 \\
\hline Capparaceae (M. B. Costa e Silva - PEUFR) & 6 & 0.39 & 0.53 & 0.52 & 0.92 & 0.46 \\
\hline 36. Capparis flexuosa $(\mathrm{L}.) \mathrm{L}$. & 6 & 0.39 & 0.53 & 0.43 & 0.92 & 0.46 \\
\hline Verbenaceae & 7 & 0.46 & 0.43 & 1.04 & 0.89 & 0.45 \\
\hline 37. Vitex rufescens A. Juss. & 2 & 0.13 & 0.35 & 0.43 & 0.48 & 0.24 \\
\hline 38. Vitex sp. & 2 & 0.13 & 0.03 & 0.43 & 0.16 & 0.08 \\
\hline Sapindaceae & 8 & 0.52 & 0.12 & 2.08 & 0.64 & 0.32 \\
\hline 39. Allophylus laevigatus Radlk. & 8 & 0.52 & 0.12 & 1.71 & 0.64 & 0.32 \\
\hline Myrsinaceae & 6 & 0.39 & $\mathbf{0 . 1 0}$ & 1.30 & 0.49 & 0.25 \\
\hline 40. Myrsine guianensis (Aubl.) Kuntze & 6 & 0.39 & 0.10 & 1.07 & 0.49 & 0.25 \\
\hline Melastomataceae & 5 & 0.33 & 0.14 & 1.30 & 0.47 & 0.23 \\
\hline 41. Miconia cf. minutiflora Bonpl. DC. & 5 & 0.33 & 0.14 & 1.07 & 0.47 & 0.24 \\
\hline Solanaceae (S.Knapp - BM) & 4 & 0.26 & 0.10 & 1.04 & 0.36 & 0.18 \\
\hline 42. Solanum inaequale Vell. & 4 & 0.26 & 0.10 & 0.85 & 0.36 & 0.18 \\
\hline Bombacaceae (A.L. Bocage-Neta - IPA) & 1 & 0.07 & 0.26 & 0.26 & 0.32 & 0.16 \\
\hline 43. Ceiba glaziovii (Kuntze) K. Schum. & 1 & 0.07 & 0.26 & 0.21 & 0.33 & 0.17 \\
\hline Fabaceae & 4 & 0.26 & 0.09 & 0.78 & 0.35 & $\mathbf{0 . 1 8}$ \\
\hline 44. Machaerium angustifolium Vogel & 2 & 0.13 & 0.07 & 0.21 & 0.20 & 0.10 \\
\hline 45. Myroxylon peruiferum L. f. & 1 & 0.07 & 0.02 & 0.21 & 0.09 & 0.05 \\
\hline 46. Platymiscium floribundum Vogel & 1 & 0.07 & 0.01 & 0.21 & 0.08 & 0.04 \\
\hline Boraginaceae & 3 & $\mathbf{0 . 2 0}$ & 0.05 & 0.26 & 0.25 & $\mathbf{0 . 1 3}$ \\
\hline 47. Cordia trichotoma (Vell.) Arráb. ex Steud. & 3 & 0.20 & 0.05 & 0.21 & 0.25 & 0.13 \\
\hline Rubiaceae & 2 & $\mathbf{0 . 1 3}$ & 0.05 & 0.26 & 0.18 & 0.09 \\
\hline 48. Rudgea jacobinensis Müll. Arg. & 2 & 0.13 & 0.05 & 0.21 & 0.18 & 0.09 \\
\hline Asteraceae & 2 & 0.13 & 0.01 & 0.52 & 0.14 & 0.07 \\
\hline 49. Verbesina macrophylla (Cass.) S.F. Blake & 2 & 0.13 & 0.01 & 0.43 & 0.14 & 0.07 \\
\hline Cactaceae & 1 & $\mathbf{0 . 0 7}$ & 0.05 & 0.26 & 0.11 & 0.06 \\
\hline 50. Cereus jamacaru DC. & 1 & 0.07 & 0.05 & 0.21 & 0.12 & 0.06 \\
\hline Bignoniaceae & 1 & 0.07 & 0.01 & 0.26 & 0.07 & 0.03 \\
\hline 51. Tabebuia sp. & 1 & 0.07 & 0.01 & 0.21 & 0.07 & 0.04 \\
\hline Dead trunks & 94 & 6.16 & 6.40 & 9.9 & 12.57 & 6.28 \\
\hline
\end{tabular}


If Sapotaceae and Combretaceae (families having less than 50 individuals per hectare, Table 2), are added to this group, the sum of the total basal area increases to $71 \%$. Although Fabaceae contained more species in this survey than Mimosaceae (both families of the Order Fabales), this is not important within the forest structure.

The Shannon diversity index (H') for species was 2.72 nats ind $^{-1}$. Seven species accounted for approximately $72 \%$ of the total IC, whereas other 30 species represented less than $1 \%$ of the IC. Myrcia fallax (Myrtaceae) alone represented $35.87 \%$ of all trunks found in this survey. Myrcia multiflora (Myrtaceae), Urera baccifera (Urticaceae), and Maprounea guianensis (Euphorbiaceae) all showed high IC values, due in great part to their high relative densities and frequencies. Manilkara salzmanii (Sapotaceae), Trichilia emarginata (Meliaceae), Terminalia brasiliensis (Combretaceae), and Gallesia integrifolia (Phytolaccaceae) stood out for their high relative dominance (Table 2): these four species accounted for $46.8 \%$ of total dominance and $10.2 \%$ of total density.

Moving vertically from understory to canopy, Sapotaceae (mainly Manilkara salzmanii), Meliaceae (Trichilia emarginata), and
Combretaceae (Terminalia brasiliensis) became increasingly important. Myrtaceae, with several species, mostly occupied the intermediate height classes, and Myrcia fallax was the most important species found in this study. It accounted for $39.4 \%$ of all individuals less than $12 \mathrm{~m}$ tall, and almost completely dominated the understory layer. Urticaceae (Urera baccifera) stood out in the $<4 \mathrm{~m}$ height class. Species such as Manilkara salzmanii and Terminalia brasiliensis were also represented in different height classes, while Gallesia integrifolia (Phytolaccaceae) was only present in the taller classes.

\section{Floristic Similarities between the Serra Negra Forest and other Regional Forests}

Cluster analysis of 155 species in 12 surveys allowed identification of three distinct groups, based primarily on their floristic composition (Fig. 3). The first group comprised all humid forests $(1,2,3)$ and some dry forests $(4,5,6)$. In the second group were two deciduous thorn woodlands $(11,12)$, and - in the third group - only dry forests $(7,8,9,10)$.

In the PCA, the first five ordination axes accounted for $65 \%$ of the variation. In Fig. 4 the first two axes suggest three groupings: one that includes

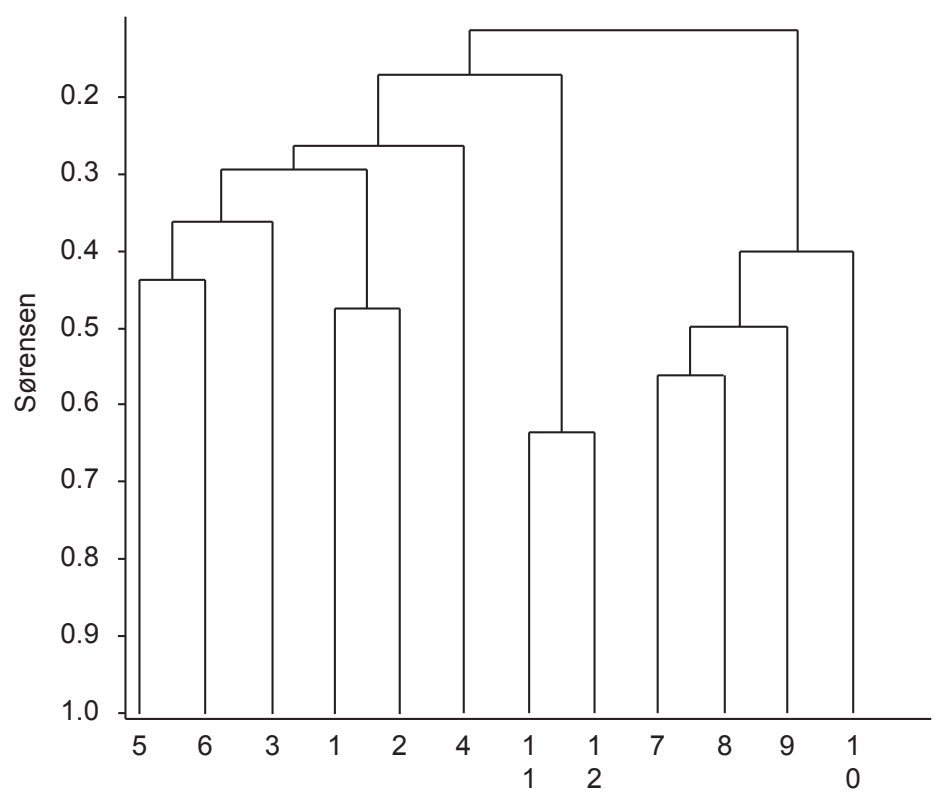

Fig. 3 - Floristic similarities between Serra Negra and other forest sites in Pernambuco state, Brazil. 1-2 = lowland humid forest; 3 = montane humid forest; 4 = lowland dry forest; $5-10=$ montane dry forest; and 11-12= deciduous thorn woodland. See information about the number of each area in Table 1. 


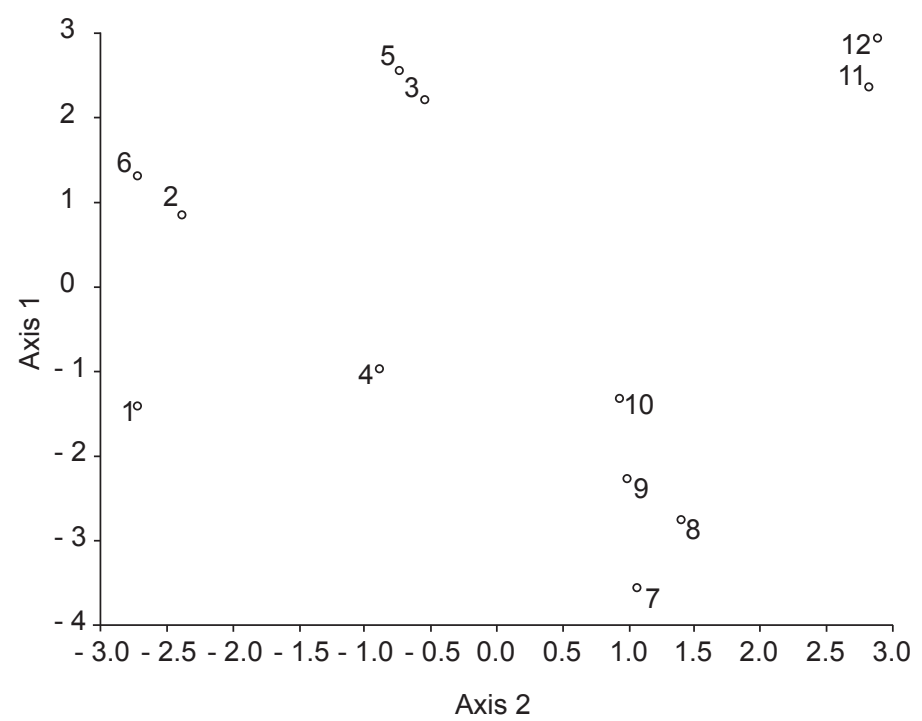

Fig. 4 - Principal component analysis between Serra Negra and other forests sites in Pernambuco state, Brazil. 1-2 = lowland humid forest; $3=$ montane humid forest; $4=$ lowland dry forest; $5-10=$ montane dry forest; and $11-12=$ deciduous thorn woodland. See information about the number of each area in Table 1.

most of the dry forests $(7,8,9,10)$; a second, deciduous thorn woodlands $(11,12)$; and a third comprising humid and dry forests $(1,2,3,5,6)$.

\section{DISCUSSION}

\section{Are there floristic and structural differences between different dry forests in northeastern Brazil?}

In the first place, the basis for distinguishing montane dry forests that are more related with humid forest near the Atlantic coast, from others that are more closely associated with seasonal plant formations characteristic of the Caatinga biome, is the flora and structure of each florest area. Thus, Rodal (2001) argues that the dry montane forests studied by Ferraz (1994), Correia (1996), and Moura (1997) are more similar to the Caatinga biome, because of the absence of species characteristic of wet environments, and the presence of many species common to the northeastern Caatinga and other deciduous plant formations in South America. Our multivariate analysis results suggest that dry forests are quite heterogeneous. These dry forests are classifiable by either of two transitional states: one, related to the Atlantic Forest biome, that represents a transition from humid $(1,2,3)$ to dry forest $(4,5,6)$, and a second representing a transition from DTW (11, $12)$ to dry forests $(7,8,9,10)$.

A revision carried out by Siqueira et al. (2001) found that the most important families in the lowland humid forests (coastal forests) of Pernambuco, Paraíba, and Alagoas states, in terms of the number of individuals, are Anacardiaceae, Lecythidaceae, Moraceae, Sapotaceae, and Burseraceae. These families, while well represented in humid lowland (Siqueira et al., 2001; Lins-e-Silva \& Rodal, in press), dry lowland (Andrade \& Rodal, 2004), and humid montane forests (Tavares et al., 2000), are only moderately or poorly represented in dry montane forest of the semi-arid region (Correia, 1996; Moura, 1997; the present research); at $700 \mathrm{~m}$ asl (Ferraz et al., 2003) and $500 \mathrm{~m}$ asl in DTW areas (Rodal et al., accepted); and at 900 (Ferraz et al., 2003) and $700 \mathrm{~m}$ asl in dry montane forest (Rodal et al., accepted).

The surveys analyzed in this paper confirmed that the family Myrtaceae had the greatest cover importance value in the dry forest of Serra Negra as well as in the dry montane forest studied by Correia (1996) and Nascimento (2001). However, a study made by Andrade \& Rodal (2004) in dry lowland forest showed that while Myrtaceae had the greatest number of species, this family had no structural importance. Surveys undertaken in DTW (Tavares et al., 1969; Alcoforado-Filho et al., 2003 
and Ferraz et al., 2003) registered the presence of Myrtaceae in areas of the Caatinga near the mountains and plateaus, as well as in the transitional zones between the humid forest and inland DTW. In these areas, again this family lacked structural importance.

Vegetation within the Caatinga (sensu stricto) at 700 (Ferraz et al., 2003) and $500 \mathrm{~m}$ asl (Rodal et al., accepted), and dry forest at 900 (Ferraz et al., 2003) and $700 \mathrm{~m}$ asl (Rodal et al., accepted) changes with altitude increase in the eastern part of the Caatinga biome (Rodal \& Sampaio, 2002). Increases in precipitation, humidity, plant size, and species number per area from the lowest in the center of the inland depression to the higher mountain areas result in the gradual substitution of DTW by dry forest.

In the lowest areas of the Caatinga biome ( $c a$. $500 \mathrm{~m}$ asl) spiny, deciduous, and highly- branched plants typical of deciduous thorn woodland (DTW or Caatinga sensu stricto) and averaging between 3 and $4 \mathrm{~m}$ in height predominate. Anacardiaceae (Schinopsis brasiliensis, Myracrodruon urundeuva, and Spondias tuberosa), Cactaceae (Pilosocereus spp. and Opuntia spp.), Euphorbiaceae (Cnidoscolus spp., Croton spp., and Jatropha spp.), Mimosaceae (Mimosa spp. and Piptadenia spp.), and Caesalpiniaceae (Caesalpinia spp.) are all typical of DTW (Rodal, 1992; Araújo et al., 1995).

Ferraz et al. (2003) observed that the DTW covering the surfaces of the semi-arid sedimentary plateaus ( $c a .700 \mathrm{~m}$ asl) was generally taller than that seen at lower elevations ( $c a .500 \mathrm{~m}$ asl). In addition to this difference, at higher altitudes other plant species became more common, e.g., Rollinia leptopetala (Annonaceae), Syagrus oleracea (Arecaceae), Tabebuia impetiginosa (Bignoniaceae), Cordia trichotoma (Boraginaceae), Peltogyne pauciflora, Platysmicium floribundum (Fabaceae), Trichilia emarginata (Meliaceae), Campomanesia eugenioides var. desertorum, Eugenia flava, E. nigra, E. tapacunensis, and Psidium rivulare (Myrtaceae), and Allophylus quercifolius (Sapindaceae).

Although in the Caatinga biome a strong relationship due to rising precipitation rates and decreasing temperatures is evident between altitude and plant height on a regional scale, this correlation may not be as noticeable on a local scale, at which plant height appears to be more strongly linked to soil water supply and local topography (Sampaio et al., 1981). At $900 \mathrm{~m}$ asl, for example, dry forest can be found that is dominated by tall trees and associated with only a few low, branched, thorny, deciduous species (typical of DTW - Caatinga sensu stricto), e.g., the Serra Negra, whereas other dry forest with tall trees exists at the same altitude but associated with a large number of those same deciduous species, as in an area studied by Ferraz et al. (2003).

Although Murphy \& Lugo (1986) observed that seasonally dry forests have a smaller stature and a lower basal area than tropical rain (humid) forests, that pattern differs from the results of the present work on the Serra Negra forest and those of other dry and humid forests in studies by other authors using similar inclusion criteria (Table 1).

Half of the surveys, such as those of dry forests $(5,7)$ and humid forests $(2,3)$, showed a total density (TD) of approximately 1,500 trunks ha ${ }^{-1}$. The occurrence of significantly lower TD values in other studies (e.g., 780 stems ha ${ }^{-1}$ in Lins-e-Silva $\&$ Rodal, in press) may be related to successional stages of regrowth, or to the degree of disturbance suffered in these areas. Considering all surveys using a $5 \mathrm{~cm} \mathrm{DBH}$, variation in basal area was positively associated only with increasing altitude ( 0.32 with $p \geq 0.09$ ), and not with subjective classification of forest areas as either dry or wet (Table 1).

\section{Do dry and humid forests in northeastern Brazil represent a single vegetational unit?}

Rodal \& Sampaio (2002) observed that the biome concept is based on being able to identify "nuclear areas", in which a greater number of the characteristics considered basic to that biome can be found, as well as "marginal areas", in which these characteristics progressively decrease until arriving at the limits of another area where the vegetative and environmental features characterize another biome. These authors pointed out, however, that this approach has two basic requirements: identifying the basic features in each biome, and selecting the minimum number necessary to establish biome boundaries. However, no consensus about these criteria exists as yet among researchers studying the largest biomes in Brazil.

The separation of Serra Negra and other montane dry forests (Correia, 1996; Moura, 1997), specifically at $700 \mathrm{~m}$ asl Rodal et al., in press) from 
dry forests that are more related to coastal forests confirms the hypothesis proposed by Pennington et al. (2004) concerning the older, and now totally fragmented, seasonally dry neotropical forest biome, which includes that of the Caatinga. For these authors, the existence of strong floristic links between well-separated areas of seasonally dry forest in South America suggests that these areas are in fact fragments of an older and much larger forest formation. They argue that the drier conditions of the Pleistocene (coinciding with glacial periods) favored expansion of dry over wet forest. To support this theory, they cite data from molecular biogeographical studies suggesting that, in many cases, the speciation of trees and shrubs in dry forest of South America pre-dates the Pleistocene.

Acknowledgments - The authors are indebted to IBAMA for authorizing this project within the Serra Negra Biological Reserve and for providing accommodation. We thank D. S. Pimentel for his help with the fieldwork, and S. J. Mayo, G. T. Prance and M. F. Sales for their support during the project "Floristic composition and diversity of the upland forests of Pernambuco."

\section{REFERENCES}

AYRES, M., AYRES, M. J., AYRES, D. L. \& SANTOS, A. S., 2000, BioEsstat 2.0: Aplicações estatísticas nas áreas das Ciências Biológicas e Médicas. Belém: Sociedade Civil Marimauá/CNPq, Brasília.

ALCOFORADO-FILHO, F. G., SAMPAIO E. V. S. B., \& RODAL M. J. N., 2003, Florística e fitossociologia de um remanescente de vegetação caducifólia espinhosa arbórea em Caruaru, Pernambuco. Acta Bot. Bras., 17: 289-305.

ANDRADE, K.V. S. A. \& RODAL, M. J. N., 2004, Fisionomia e estrutura de um remanescente de floresta estacional semidecidual de terras baixas no nordeste do Brasil. Rev. Bras. Bot., 4: 463-474.

ANDRADE, G. O., 1954, Serra Negra: uma relíquia geomórfica e higrófita nos tabuleiros pernambucanos. Imprensa Oficial, Recife.

ARAÚJO, E. L., SAMPAIO, E. V. S. B., \& RODAL, M. J. N., 1995, Composição florística e fitossociologia de três áreas de Caatinga de Pernambuco. Rev. Bras. Biol., 55: 595-607.

BORGES, M. S., 1992, Composição florística e estrutura da mata de Dois Irmãos, Recife - PE. B.Sc. monograph, Universidade Federal Rural de Pernambuco, Recife.

CAVALCANTI, M. S., 1985, Aspectos da vegetação da Mata do Jardim Botânico do Curado. Recife. B.Sc. monograph, Universidade Federal de Pernambuco, Recife.

COIMBRA-FILHO, F. \& CÂMARA, I. G., 1996, Os limites originais do Bioma Mata Atlântica na Região Nordeste do Brasil. Fundação Brasileira para Conservação da Natureza - FBCN, Rio de Janeiro.
CORREIA M. S., 1996, Estrutura da vegetação da mata serrana de um brejo de altitude de Pesqueira-PE. MSc dissertation, Universidade Federal de Pernambuco, Recife.

CRONQUIST, A., 1981, An integrated system of classification of flowering plants. Columbia University Press, New York.

DANTAS, J. R. A., 1980, Mapa geológico do estado de Pernambuco. Departamento Nacional de Produção Mineral, Recife.

FERRAZ, E. M. N., 1994, Variação florístico-vegetacional na região do vale do Pajeú, Pernambuco. MSc dissertation, Universidade Federal Rural de Pernambuco, Recife.

FERRAZ, E. M. N., RODAL, M. J. N. \& SAMPAIO, E. V. S. B., 2003, Physiognomy and structure of vegetation along an altitudinal gradient in the semi-arid region of northeastern Brazil. Phytocoenologia, 33: 71-92.

FIGUEIRÊDO, L. S., RODAL, M. J. N. \& MELO, A. L., 2000, Florística e fitossociologia de uma área de vegetação arbustiva caducifólia no município de Buíque-Pernambuco. Naturalia, 25: 33-46.

GENTRY, A. H., 1995, Diversity and floristic composition of neotropical dry forests, pp. 146-194. In: H. A. Mooney, S. H. Bullock, \& E. Medina (eds.), Dry tropical forests, Cambridge University Press, Cambridge.

GILLESPIE, T. W., GRIJALVA, A. \& FARRIS, C. N., 2000, Diversity, composition, and structure of tropical dry forests in Central America. Plant Ecology, 147: 37-47.

GUEDES, M. L. S., 1998, A vegetação fanerogâmica da reserva Ecológica de Dois Irmãos, pp.157-172. In: I. C. S. Machado, A. V. Lopes. \& K. C. Porto (eds.), Reserva Ecológica de Dois Irmãos: estudos em um remanescente de Mata Atlântica em área urbana, Recife - Pernambuco - Brasil, Editora Universitária, Recife.

IBAMA, 1989, Unidades de conservação do Brasil: parques nacionais e reservas biológicas. Ministério do Interior, Brasília.

JACOMINE, P. T., CAVAlCANTI, A. C., BURGOS, N., PESSOA, S. C. P. \& SILVEIRA, C. O., 1973, Levantamento exploratório-reconhecimento de solos do Estado de Pernambuco. V. 1 Divisão de Pesquisa Pedológica. Recife. (Boletim Técnico 26, Pedologia 14).

JANZEN, D., 1997, Florestas tropicais secas: o mais ameaçado dos grandes ecossistemas tropicais, pp. 177-185. In: O. Wilson (ed.), Biodiversidade, Nova Fronteira, Rio de Janeiro.

JOLY, C. A., AIDAR, M. P. M., KLINK, C. A., McGRATH, D. G., MOREIRA, A. G., MOUTINHO, P., NEPSTAD, D. C., OLIVEIRA, A. A., POT, A., RODAL, M. J. N., \& SAMPAIO, E. V. S. B., 1999, Evolution of the Brazilian phytogeography classification systems from the biodiversity conservation point of view. Ciência \& Cultura, 51: 331-348.

KENT, M. \& COKER, P., 1992, Vegetation description and analysis: a practical approach. John Wiley and Sons, London.

LINS-e-SILVA, A. C. B. \& RODAL, M. J. N., in press, Tree Community Structure in an Urban Atlantic Forest Remnant in Pernambuco, Brazil. Memoirs of New York Botanical Garden. 
LÜETTGE, U., 1997, Physiological Ecology of Tropical Plants. Springer - Verlag, Berlin.

MAGURRAN, A. E., 1988, Ecological diversity and its measurement. Princeton University, New Jersey.

MATEUCCI, S. D. \& COLMA, A., 1982, Metodología para el estudio de la vegetación. Secretaria General de la Organización de los Estados Americanos. Programa Regional de Desarrollo Científico y Tecnológico, Washington.

MOONEY, H. A., BULLOCK, S. H., \& MEDINA, E., 1995, Introduction, pp. 1-8. In: H. A. Mooney, S. H. Bullock \& E. Medina (eds.), Dry tropical forests, Cambridge University Press, Cambridge.

MOREIRA, A. A. N., 1977, Relevo, pp. 1-45. IBGE (ed.), Geografia do Brasil - Região Nordeste, IBGE, Rio de Janeiro.

MOURA, F. de B. P., 1997, Fitossociologia de uma mata serrana semidecídua no brejo de Jataúba, Pernambuco. M.Sc. dissertation, Universidade Federal de Pernambuco, Recife.

MURPHY, G. \& LUGO, A. E., 1986, Ecology of tropical dry forests. Ann. Rev. Ecol. Syst., 17: 67-88.

NASCIMENTO, L. M. do, 2001, Caracterização fisionômicoestrutural de um remanescente de floresta montana no nordeste do Brasil. M. Sc. dissertation, Universidade Federal Rural de Pernambuco, Recife.

OLIVEIRA-FILHO, A. T. \& RATTER, J. A., 2000, Padrões florísticos das matas ciliares da região do cerrado e a evolução das paisagens do Brasil Central durante o Quaternário tardio, pp. 73-90. In: R. R. Rodrigues \& H. F. Leitão-Filho (eds.), Matas ciliares: conservação $e$ recuperação, EDUSP, São Paulo.

PENNINGTON, R. T., PRADO, D. E. \& PENDRY, C. A., 2000, Neotropical seasonally dry forests and Quaternary vegetation changes. J. Biog., 27: 261-273.

PENNINGTON, R. T., LAVIN, M., PRADO, D. E., PENDRY, C. A., PELL, S. K. \& BUTTERWORTH, C. H., 2004, Historical climate change and speciation: neotropical seasonally dry forest plans show patterns of both Tertiary and Quaternary diversification. Phil. Trans. R. Soc. Lond., 359: 315-338 B.

RICHARDS, P. W., 1996, The tropical Rain Forest: An ecological study. 2nd edn. Cambridge University Press, London.

RODAL, M. J. N., 1983, Fitoecologia de uma área do médio vale do Moxotó, Pernambuco. MSc dissertation, Universidade Federal Rural de Pernambuco, Recife.

RODAL, M. J. N., 1992, Fitossociologia da vegetação arbustivo-arbórea em quatro áreas de Caatinga em Pernambuco. Ph.D. thesis - Universidade Estadual de Campinas. Campinas.

RODAL, M. J. N., 2001, Montane forests in Northeast Brazil: a phytogeographical approach. Botanische Jahrbücher für Systematik, Pflanzengeschichte und Pflanzengeographie, 124, 1-10.

RODAL, M. J. N. \& SAMPAIO, E. V. S. B., 2002, A vegetação do bioma Caatinga, pp. 11-24. In: E. V. S. B. Sampaio, A. M. Giulietti, J. Virgínio, \& C. F. L. Gamara-Rojas (eds.),
Vegetação e Flora da Caatinga, Associação Plantas do Nordeste, Recife.

RODAL, M. J. N., LINS-e-SILVA, A. C. B. \& COSTA, K. C. C., accepted, Local scale variation in plant community attributes in the Semi-arid region, Northeastern Brazil. Journal of Arid Environments.

SAMPAIO, E. V. S. B., ANDRADE-LIMA, D. de \& GOMES, M. A. F., 1981, O gradiente vegetacional das caatingas e áreas anexas. Rev. Bras. Bot., 4: 27-30.

SAMPAIO, E. V. S. B., 1995, Overview of the Brazilian Caatinga, pp. 35-63. In: H. A. Mooney, S. H. Bullock, \& E. Medina (eds.), Dry tropical forest. Cambridge University Press, Cambridge.

SARMIENTO, G., 1972, Ecological and floristic convergences between seasonal plant formations of tropical and subtropical South. America. J. Ecol., 60: 367-410.

SCUDELLER, V. V, MARTINS, F. R. \& SHEPHERD, G., 2001, Distribution and abundance of arboreal species in the Atlantic ombrophilous dense forest in Southeastern Brazil. Plant Ecology, 152: 185-199.

SHEPHERD, G. J., 1995, FITOPAC 2. Manual do usuário. Departamento de Botânica, UNICAMP, Campinas.

SILVA, F. B. R., RICHÉ, G. R., TONNEAU, J. P., SOUZANETO, N. C., BRITO, L. T. L., CORREIA, R. C., CAVALCANTI, A. C., SILVA, F. H. B. B., SILVA, A.B., ARAÚJO-FILHO, J. C. \& LEITE, A. P., 1993, Zoneamento agroecológico do nordeste: diagnóstico do quadro natural $e$ agrossocioeconômico. $2^{\circ}$ vol. EMBRAPA-CPATSA/ CNPS, Petrolina.

SIQUEIRA, D. R., RODAL, M. J. N., LINS-e-SILVA, A. C. B. \& MELO, A. L., 2001, Physiognomy, structure and floristics in an area of Atlantic Forest in Northeast Brazil, pp. 11-27. In: G. Gottsberger. \& S. Lied (eds.), Proceedings of Life Forms and Strategies in Tropical Forests., Gebr. Borntraeger Verlagsbuchhandlung, Berlin-Stuttgart.

SUDENE, 1990, Dados pluviométricos mensais do Nordeste. Estado de Pernambuco. Superintendência do Desenvolvimento do Nordeste, Recife. (Pluviometria, 6).

TAVARES, M. C., RODAL M. J. N., MELO, A. L. \& LUCENA, M. F. A., 2000, Fitossociologia do componente arbóreo de um trecho de Floresta Ombrófila Montana do Parque Ecológico João Vasconcelos-Sobrinho, Caruaru, Pernambuco. Naturalia, 25: 17-32.

TAVARES, S., PAIVA, F. A. V., TAVARES, E. J. DE S., LIMA, J. L. S. DE \& CARVALHO, G. H., 1969, Inventário florestal de Pernambuco. Estudo preliminar das matas remanescentes do município de São José do Belmonte. Bol. Rec. Nat., 7: 113-139.

THOMAS, W. W., CARVALHO, A. M., AMORIM, A. M., GARRISON, J. \& ARBELAEZ, A. L., 1998, Plant endemism in two forests in southern Bahia, Brazil. Biod. Conserv., 7: 311-322.

TREJO, I. \& DIRZO, R., 2000, Deforestation of seasonally dry forest: a national and local analysis in Mexico. Biol. Conserv., 94: 133-142.

VELOSO, H. P., RANGEL-FILHO, A. L. R. \& LIMA, J. C. A., 1991, Classificação da vegetação brasileira, adaptada a um sistema universal. IBGE, Rio de Janeiro. 